\title{
PLEISTOCENE STRATIGRAPHY OF POLAND AND ITS CORRELATION WITH STRATOTYPE SECTIONS IN THE VOLHYNIAN UPLAND (UKRAINE)
}

\author{
LESZEK LINDNER and LESZEK MARKS \\ Institute of Geology, University of Warsaw \\ Żwirki i Wigury 93, 02-089 Warsaw
}

Received 10 January 2008

Accepted 08 February 2008

\begin{abstract}
Recent stratigraphic subdivision of the Pleistocene of Poland presents 4 complexes: Preglacial, South-Polish, Middle-Polish and North-Polish ones. Each complex comprises a set of stratigraphic units, corresponding to the previously distinguished 8 glaciations/coolings and 7 interglacials/warmings. Three younger complexes and corresponding extents of Scandinavian ice sheets in Poland are described in more detail. Three older interglacials in Poland (Augustovian, Kozi Grzbiet and Ferdynandovian) are characteristic for their bi-optimal climatic sequences but so far, they have no equivalents in loess sections of the Volhynian Upland in the Ukraine. Coolings between the optima of these interglacials are occasionally considered as small glaciations, during which the ice sheet could occupy only a northern part of Poland. All younger interglacials are mono-optimal in Poland and as such, they are also reflected by single palaeosols in loess sections of both countries. Till occurrences in key loess sections of Poland and Ukraine enabled precise delimitation of ice sheet extents, especially within the Middle-Polish Complex with the glaciations Liwiecian, Krznanian and Odranian ascribed to OIS 10, 8 and 6, respectively. During the youngest (Vistulian, Valdai) Glaciation, 3-4 loess deposits were formed in the Lublin and Volhynian Uplands; they are separated by palaeosols that developed during interstadial-rank warmings.
\end{abstract}

Keywords: complexes, interglacials, glaciations, stratotype sections, loess, palaeosols, Pleistocene, Poland, Ukraine.

\section{INTRODUCTION}

Pleistocene glaciations and interglacials distinguished in the territory of Poland are the principal units of the stratigraphic subdivision of the glacial part of the Quaternary in Poland (1.4-0.01 Ma). Limits of some of these glaciations (Sanian 1, Sanian 2, Odranian and Vistulian in Fig. 1) are expressed by glacial landforms and sediments, whereas the others (Narevian, Nidanian, Liwiecian and Krznanian in Fig. 2) are represented by buried deposits, overlain by younger glacial series. All glaciations and interglacials are correlated with reliable Middle and Late Pleistocene stratigraphic horizons in the stratotype sections Bojanice and Korshiv in the Volhynian Upland (Figs 1, 3). These sections have been examined for almost 30 years (among others Boguckij et al., 1980;

Corresponding author: L. Lindner

e-mail: 1.lindner@uw.edu.pl

ISSN 1897-1695 (online), 1733-8387 (print) (C) 2008 GADAM Centre,

Institute of Physics, Silesian University of Technology.

All rights reserved.
Bogucki et al., 1995; Szełkoplyas et al., 1985; Szełkoplyas and Christoforowa, 1987). They contain tills (Bojanice) as well as loess deposits and separating palaeosols (Bojanice, Korshiv) that were correlated with the Pleistocene main stratigraphic units in western and mideastern Europe (among others Lindner et al., 1998; Lindner and Marciniak, 1998).

Recent proposal of an updated stratigraphic time table of the Pleistocene of Poland (Ber et al., 2007a, b) presents 4 complexes, namely Preglacial, South-Polish, Middle-Polish and North Polish ones. Each complex comprises a set of stratigraphic units, including the previously distinguished glaciations/coolings and interglacials/warmings (Fig. 2).

The paper is a short description of three younger complexes, with their glaciations and interglacials, correlated with main units (horizons) of the stratigraphic subdivision of the Pleistocene in the Volhynian Upland in the Ukraine (Fig. 3). Besides, maximum limits of Scandina- 


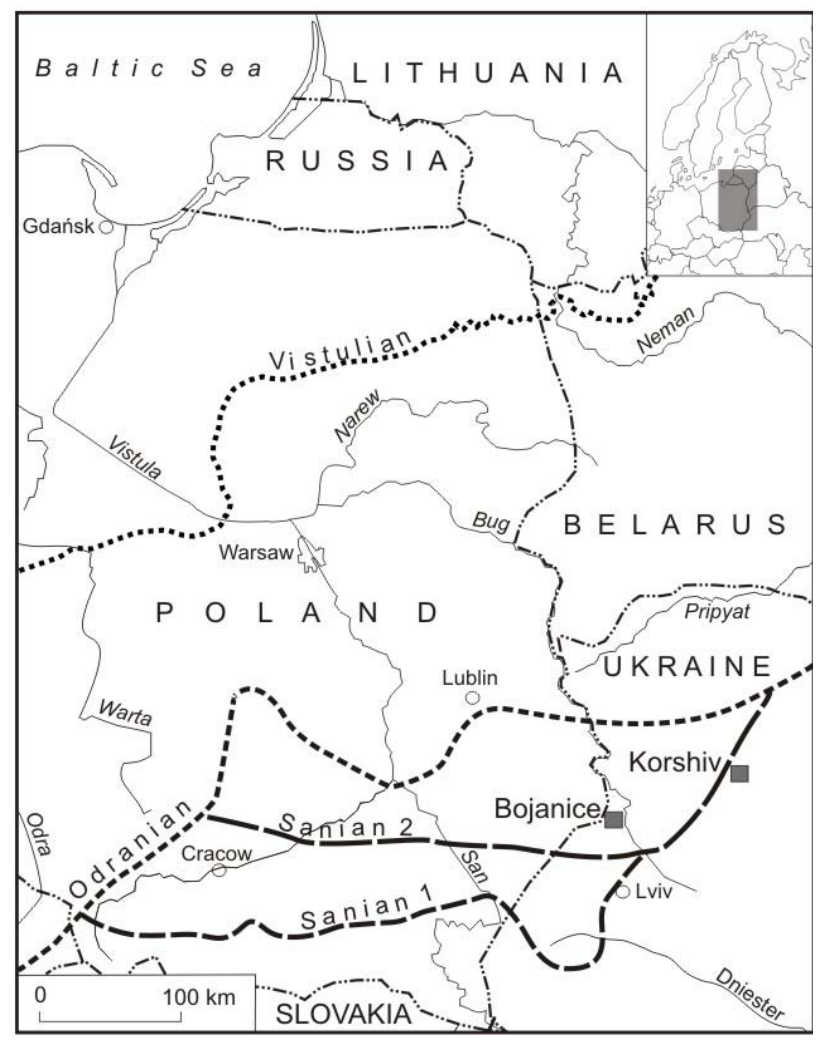

Fig. 1. Limits of main Scandinavian glaciations in eastern Poland and neighbouring countries and location of the stratotype sites Bojanice and Korshiv.

vian ice sheets (cf. Marks, 2004a) in eastern Poland, western Belarus and Ukraine are presented (Fig. 1). During the last few years the distinguished stratigraphic units of the South-Polish Complex, have been supported by numerous new key sites and therefore, more detailed palaeogeographic and palaeobotanic evidence is available (Janczyk-Kopikowa, 1996; Winter, 2001; Marciniak and Winter, 2003; Pidek, 2003; Lisicki and Winter, 2004; Wójcik et al., 2004). Such approach enabled to delimit extents both of older and younger glaciations. On the other hand, analysis of till occurrences in stratotype loess sections of Poland and Ukraine (Lindner et al., 2004) founded the basis to delimit Scandinavian glaciations within the Middle-Polish Complex (Lindner, 2005). In this very case, it concerns particularly Liwiecian and Krznanian glaciations (corresponding to OIS 10 and 8, respectively), but also the Odranian Glaciation, together with its recession Warta, Wkra and Mława stades corresponding to OIS 6.

\section{SOUTH-POLISH COMPLEX}

The Narevian Glaciation is the oldest unit of this complex (Fig. 2). The Scandinavian ice sheet invaded northern Poland, slightly more southwards to the west than presented previously (cf. Lindner and Marks, 1995). In the west it reached the Lower Odra and Middle Noteć valleys and in the east, it occupied a northern part of the Radom Plain and Lublin Upland. In mid-western Poland a distinct proglacial outflow system was developed whereas vast ice-dam lakes occurred in eastern Poland.
During the Augustovian Interglacial (Fig. 2), previously known as the Podlasie Interglacial, a vast lake was formed in northern part of the present Biebrza Basin (near Augustów in north-eastern Poland). Organic sediments of this lake were examined in several borehole sections (Ber, 2000) and document a bi-optimal floristic succession (among others Janczyk-Kopikowa, 1996; Marciniak and Winter, 2003; Lisicki and Winter, 2004), different from the younger interglacials in Poland due to the absence of fir (Abies) and hornbeam (Carpinus) in the lower optimum. Bi-optimal succession of this interglacial is also supported by isotope analysis of ${ }^{13} \mathrm{C}$ and ${ }^{18} \mathrm{O}$ by Jędrysek (Ber, 2000). Deposits at the setting of this interglacial from the section Kijewice (northern Mazovia) were TL dated at 890-820 ka (Bałuk, 1991). In the Carpathians, the age of the fluvial sediments of this interglacial, comprising reverse magnetic polarisation (Matuyama Epoch), was TL dated at $749 \pm 112 \mathrm{ka}$ (Butrym and Zuchiewicz, 1985).

During Nidanian Glaciation (Fig. 2) the Scandinavian ice sheet occupied not only Central Poland but spreading along the Sudetes, it reached the Moravian Gate and western foreland of the Carpathians. Its presence, indicated by a till at Kończyce (Oświęcim Basin) seems to be supported by palaeomagnetic examination that determined the setting of the Bruhnes/Matuyama boundary $(778 \mathrm{ka})$ in the overlying interglacial deposits (Wójcik et al., 2004). The front of the ice sheet along the northern edge of the Małopolska and Lublin uplands dammed the rivers flowing to the north, what resulted in development of proglacial lakes. Anaglacial part of his glaciation is connected with deposition of the oldest subtill loess in Poland, particularly well preserved on slopes of buried fluvial valleys in the western part of the Holy Cross Region (Lindner, 1991).

During the Kozi Grzbiet (Domuraty) Interglacial (Fig. 2), an exceptionally rich accumulation of fauna remains formed in the cave Kozi Grzbiet in the Holy Cross Region. These remains, comprising abundant bones and teeth of mammals, amphibians, reptiles and also shells of terrestrial snails, represent a bi-optimal warming that corresponds to the Dutch Cromer II. The Brunhes/Matuyama palaeomagnetic boundary preserved in cave deposits (Głazek et al., 1977), enabled their correlation with OIS 19. These cave deposits are presumably of the same age as lake sediments in the southern part of the present Biebrza Basin in north-eastern Poland, among others at Domuraty. They represent (Lisicki and Winter, 2004) a bi-optimal floristic succession, younger than the one of the Augustovian Interglacial and different by its co-occurrence of hornbeam (Carpinus) and fir (Abies) during the second optimum, as well as presence of ash (Fraxinus) during the mid-interglacial cooling. The above mentioned interglacial lake sediments from the section Kończyce (Wójcik et al., 2004) are presumably of the same age.

During the Sanian 1 Glaciation (Fig. 2) the Scandinavian ice sheet occupied the largest area of Poland. It reached both the Sudetes and the Carpathians (Fig. 1), invading them with immense lobes that used the river valleys open to the north, among them the Upper Odra valley in the Moravian Gate (Lindner, 2001). In its mar- 


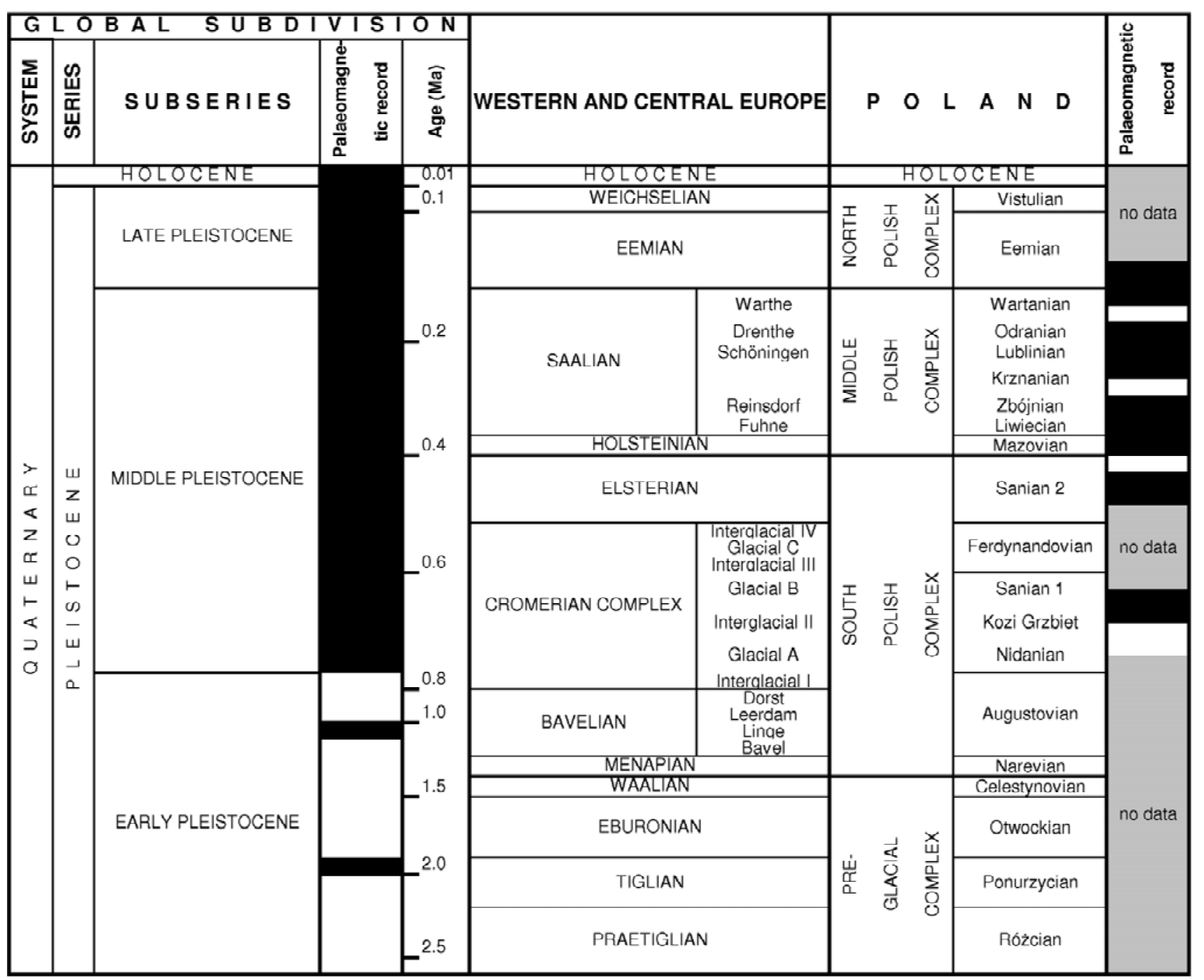

Fig. 2. Stratigraphic subdivision of the Quaternary of Poland and its correlation with eastern Europe, after Ber et al. (2007a, b), supplemented.

ginal part the ice sheet moved around high-elevated area (main ranges of the Holy Cross Mountains, Polish Jura, Ślęża), favouring development of abundant nunataks. The next sub-till loess was also deposited, preserved at present in western and southern parts of the Holy Cross Region (Lindner, 1991) and recently found also in the Lublin Upland near Hrubieszów (Dolecki, 2002). In the neighbouring Dubienka Basin to the north of Hrubieszów, there are corresponding (TL age 680-620 ka) lake sediments, containing mostly aeolian material, presumably being an aquatic facies of loess (Dolecki, 2002). This loess in Poland probably corresponds to the oldest loess in the Volhynian Upland (Lindner et al., 1998), preserved in the section Bojanice (Fig. 3) and defined as the Don (Sula) horizon.

The Ferdynandovian Interglacial (Fig. 2) is also expressed by a bi-optimal climatic succession (JanczykKopikowa, 1991); it is characteristic for presence of hornbeam (Carpinus) but in the second optimum only. Diatomologic investigations of lake sediments in the territory of Poland evaluated water level changes (Marciniak and Lindner, 2003). A mid-interglacial cooling is considered for a small glaciation, during which the Scandinavian ice sheet reached the northern part of Poland
(Pidek, 2003). TL dating suggest the age limits of this interglacial from $543 \pm 65 \mathrm{ka}$ to $522 \pm 63 \mathrm{ka}$ (Rzechowski, 1996). In the Volhynian Upland this interglacial corresponds presumably to fluvial(?) erosion and accumulation, recorded in the section Bojanice (Fig. 3) and represented by sands with gravels and sands above the oldest loess horizon. It can also correspond to the Lubny (Solotvin) palaeosol horizon (Boguckyj and Łanczont, 2002).

The Sanian 2 Glaciation (Fig. 2) is the youngest stratigraphic unit of the South-Polish Complex. During this glaciation the Scandinavian ice sheet, after advance around the Holy Cross Mountains and occupation of the Lublin Upland, entered the Sandomierz Basin (Fig. 1); it reached also the north-eastern slopes of the Sudetes. Similarly as during the preceding glaciation, the highest ranges of the Holy Cross Mts and some intermontane basins formed the nunataks. At the edge of the Carpathians a latitudinal marginal valley was formed: it collected proglacial and extraglacial waters and drained them to the Dniester drainage basin. In the Holy Cross Region ice sheet advance was preceded by deposition of a sub-till loess (Lindner, 1991). The loess in a similar geologic setting was also noted near Hrubieszów in the Lublin Upland (Dolecki, 2002). The corresponding loessy-like 


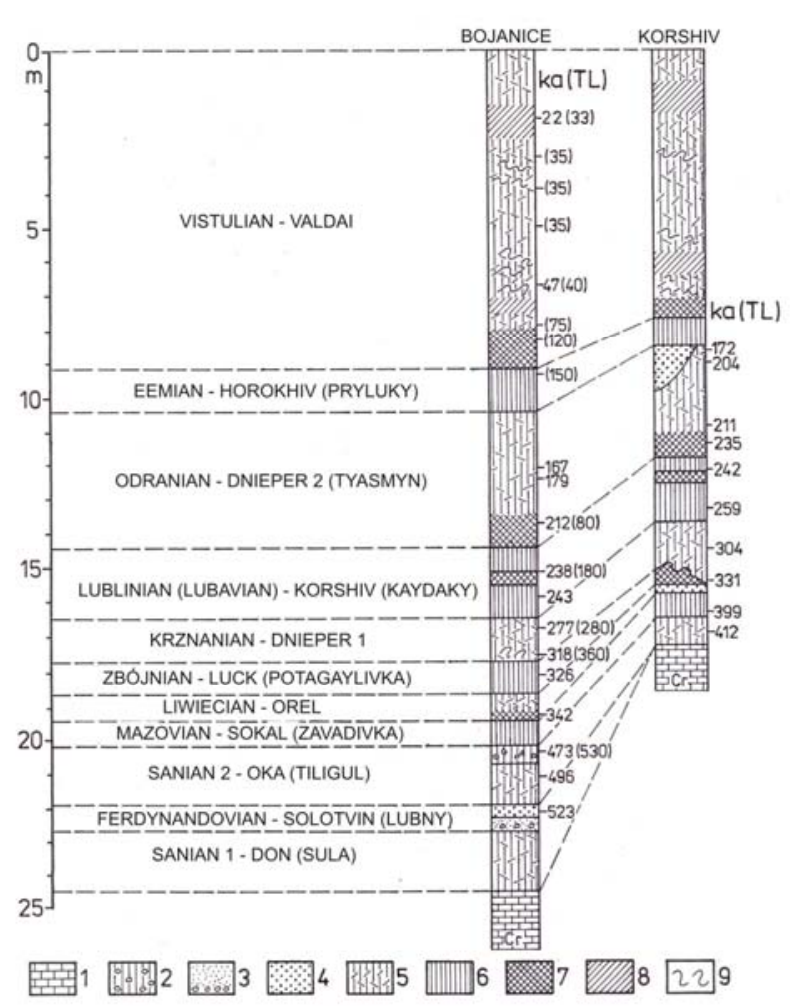

Fig. 3. Stratigraphic setting and thermoluminescence age of Pleistocene deposits in sites Bojanice and Korshiv, after Lindner et al. (1998), updated.

1 - Cretaceous marls; 2 - till; 3 - sands with gravels; 4 - sands; 5 - loess; 6 - illuvial horizons (B) of interglacial forest soils; 7 - chernozems; 8 - interstadial tundra soils; 9 - soliflucted deposits; age TL in ka after Butrym (Bogucki et al., 1995; Szetkoplyas et al., 1985), in brackets after Shelkoplyas (Szełkoplyas et al., 1985; Szełkoplyas and Christoforowa, 1987).

loams in the Carpathians were TL dated at $476 \pm 71 \mathrm{ka}$ (Butrym and Zuchiewicz, 1985) and at the section Załubińcze - they comprised the palaeomagnetic episode Empereur (Nawrocki and Wójcik, 1995). In the section Korshiv and the second (from the bottom) loess in the section Bojanice they correspond to the oldest loess (Fig. 3). This horizon Tiligul is referred, together with the overlying till, to the Oka Glaciation (Lindner et al., 1998).

\section{MIDDLE-POLISH COMPLEX}

The Mazovian Interglacial is the oldest unit of this complex in Poland (Fig. 2) and it is represented by abundant sites with lake-boggy deposits that, basing on palaeobotanic analyses, determine climatic conditions of this interval. Palynologic analyses indicate (among others Krupiński, 2000) that the climatic optimum of this interglacial is indicated by maximum development of oak (Quercus), elm (Ulmus), linden (Tilia), hazel (Corylus) and hornbeam (Carpinus). On the other hand, diatomologic analyses (Marciniak, 1998) enable to examine the lake water level fluctuations. In the section Krępiec, Lublin Upland, lake sediments of this interglacial were TL dated at 400-350 ka (Harasimiuk et al., 1988) and fluvial sediments with Holstein-type fauna at Serniki - at 440-400 ka. Bones of a cave bear from the same interval are known from a karst section at Draby near Działoszyn, dated by $\mathrm{FCl} / \mathrm{P}$ and collagen method at 440-320 ka (Głazek et al., 1976). The Mazovian Interglacial in loess sections is represented by palaeosols, noted both in boreholes and exposures in the Lublin Upland (Dolecki 2002). In the Volhynian Upland it is represented by a palaeosol of the Sokal (Zavadivka) horizon, noted in the sections Bojanice and Korshiv (Fig. 3).

The Liwiecian Glaciation (Fig. 2) is represented by a till that delimits ice sheet extent in north-eastern and mideastern Poland. A vast proglacial lake was formed by damming the Vistula valley and its tributaries to the south of Warsaw. In the section Zbójno near Przedbórz, sediments of this lake were TL dated at $388 \mathrm{ka}$ (Lindner and Brykczyńska, 1980). In western Poland two latitudinal valley systems were formed (based on relic network from the preceding interglacial) that drained proglacial and extraglacial waters westwards, to the Elbe drainage basin. Similar system but to east was directed to the Pripyat drainage basin. During the anaglacial part of the Liwiecian Glaciation, deposition of the oldest supra-till loess deposits in the Lublin Upland occurred (Maruszczak, 1991; Dolecki, 2002). In the section Nieledew they are bracketed by TL dates from $367.8 \mathrm{ka}$ to $351 \mathrm{ka}$. In the Volhynian Upland these loess deposits correspond to the loess of the horizon Orel (with a thin chernozem at the bottom), preserved in the section Bojanice, and possibly also to a thin layer of sand in the section Korshiv (Fig. 3).

The Zbójnian Interglacial (Fig. 2) is indicated by lake-boggy deposits known from several key sections in Poland. In the section Zbójno near Przedbórz a palynologic succesion records palaeoclimatic conditions, expressed firstly by exceptionally large participation (to $48 \%$ ) of linden (Tilia), with abundant hornbeam (Carpinus), alder (Alnus) and hazel (Corylus) during climatic optimum (Lindner and Brykczyńska, 1980). TL age of these deposits is less than $388 \mathrm{ka}$ and older than $236 \mathrm{ka}$ (Lindner and Marciniak, 1998). Fluvial sediments of the Zbójnian Interglacial were TL dated in the section Wąchock near Starachowice at $352 \mathrm{ka}$ (Lindner and Prószyński, 1979). This interglacial is also indicated by a palaeosol in the loess sections of the Lublin Upland (Maruszczak, 1991; Dolecki, 2002). In the section Nieledew this interglacial is represented by a palaeosol, developed on the oldest supra-till loess, TL dated at $367 \mathrm{ka}$ and overlain by the lowermost older loess, TL dated at $300 \mathrm{ka}$. In the Volhynian Upland this interglacial is represented by the mid-loessy palaeosol of the horizon Luck (Potagaylivka), preserved both at Bojanice and at Korshiv (Fig. 3).

During the Krznanian Glaciation (Fig. 2), previously treated as the pre-maximum stade of the Odranian Glaciation (cf. Lindner and Marks, 1999; Lindner, 2005), the Scandinavian ice sheet reached not only the foreland of the Małopolska and Lublin Uplands but also the ForeSudetic Lowland. TL age of glacial deposits was determined at $273 \mathrm{ka}$ in the section Marianka on the Włodawa Elevation, whereas at $298 \mathrm{ka}$ and $250 \mathrm{ka}$ in the Sudetes and their foreland (Szponar, 1986). Traces of a proglacial 
outflow to the west are best preserved in the westernmost foreland of the Sudetes. Loess of this interval (the socalled older lower loess) is preserved in several patches in south-eastern Poland (Lindner, 1991; Maruszczak, 1991) and TL dated at 298-260 ka. The Carpathian loess (section Załubińcze) of this glaciation comprises a palaeomagnetic episode Chegan (Nawrocki and Wójcik, 1995). In the Volhynian Upland this loess corresponds to the horizon Dnieper 1, preserved both at Bojanice as at Korshiv (Fig. 3).

Palynology of the Lublinian (Lubavian) Interglacial (Fig. 2) is represented by the site Losy near Lubawa, with lake sediments containing incomplete floristic succession (eroded upper part of the section) and floristic image, different from the Eemian Interglacial one by earlier entrance of linden (Tilia) than hazel (Corylus) and also by presence of Azolla (Krupiński and Marks, 1986). Sediments of this interglacial are bracketed by TL ages of $270 \mathrm{ka}$ and $181 \mathrm{ka}$. In loess sections this interglacial is indicated by a palaeosol of "Tomaszów" type (Jersak, 1973), defined by Maruszczak (1991) as an interglacial type soil (GI2), capped with an interstadial soil (Gi/GI2). TL dating of the older and younger loess determine setting of the described complex as younger than $255.8 \mathrm{ka}$ and older than $221.3 \mathrm{ka}$. In the Volhynian Upland this soil should correspond to the Korshiv soil complex (Kaydaky), preserved both at Bojanice and Korshiv (Fig. 3).

The Odranian Glaciation (Fig. 2) is the youngest stratigraphic unit of the Middle-Polish Complex. During this glaciation the Scandinavian ice sheet reached the Sudetes, entered deeply into the Moravian Gate, advanced to northern slopes of Małopolska (Polish Jura, Holy Cross Mts) and Lublin Uplands, and came to the northern part of the Sandomierz Basin (Fig. 1). Similarly as during earlier glaciations, it resulted in development of ice-dam lakes in the valleys of Pilica, Vistula and Wieprz rivers. Deglaciation resulted in development of well expressed rows of end moraines of the Warta Stade (previously Wartanian Glaciation), as well as of Wkra and Mławka stades (Lindner, 2005). In the anaglacial part of this glaciation, deposition of the so-called older upper loess occurred (Maruszczak, 1991) and continued later during ice sheet recession of the Warta Stade (cf. Marks, $2004 b$ ). TL age of this loess was determined in the section Nieledew at 221.3 to $159.3 \mathrm{ka}$. In the Carpathian (Załubińcze) and Małopolska (Odonów) sections the loess of this glaciation comprises a palaeomagnetic episode Jamaica (Nawrocki and Wójcik, 1995; Nawrocki and Siennicka-Chmielewska, 1996). In the Volhynian Upland the loess of the Dnieper 2 (Tyasmin) horizon was deposited, preserved both at Bojanice and at Korshiv (Fig. 3).

\section{NORTH-POLISH COMPLEX}

The Eemian Interglacial (Fig. 2) is the oldest unit of the North-Polish Complex. During this interglacial, a sea ingression occurred in the present Lower Vistula Valley region, indicated by sediments of the so-called Tychnowy Sea, containing fauna remains, among which foraminifers and molluscs are the most important (among others Makowska, 1986). Marine sediments of the Eemian Intergla- cial were also found near Rewal in western Pomerania (Krzyszkowski et al., 1999). Lake-boggy sediments of the Eemian Interglacial are known from many sites in Poland. Their palynological analysis indicates that a climatic optimum was predominated by deciduous forest with climax of oak (Quercus), then hazel (Corylus), with abundant elm (Ulmus) and linden (Tilia); the latter reached its climax later than hazel (among others Mamakowa, 1989). Water level fluctuations in the Eemian lakes were recorded by diatomologic investigations, initiated already many years ago (among others Marciniak and Kowalski, 1978). In loess sections of southern Poland this interglacial is indicated by the lower part of the soil complex of the type "Nietulisko I" (Jersak, 1973), determined by Maruszczak (1991) mainly as a forest brown and brown leached soil (GI1). According to him, basing on TL dating of the underlying and overlying loess deposits, this soil developed from $130-125 \mathrm{ka}$ to $115-110 \mathrm{ka}$. In the loess sections of Bojanice and Korshiv (Fig. 3), it corresponds to the lower part of the Horokhiv (Pryluky) soil complex. In caves of the Tatra Mts, carbonate speleothems were formed, Th/U dated at $124_{-16}^{+60} \mathrm{ka}$ (Głazek, 1984).

During the Vistulian Glaciation (Fig. 2) the Scandinavian ice sheet reached its maximum extent during the so-called Main (Leszno-Poznań) Stadial. The ice sheet occupied a predominant part of northern and central Poland (among others Marks, 1998, 2002), reaching Zielona Góra and Konin, but also an immense lobe came to the Płock Region (Fig. 1) where a vast ice-dam lake was formed, filling the Vistula Valley upstream as far as the area of Warsaw. Further to the east, the ice sheet limit was smaller: it occupied Mazury and Suwałki lakelands reaching south to Nidzica, Kolno and Sztabin. Basing on radiocarbon dating of organic deposits under the till of the Main Stadial and analyses of varved clays, connected with ice sheet retreat, its standstill during the maximum of the Leszno Phase occurred at about $21 \mathrm{ka}$ BP and during the Gardno Phase - at about 14-13.8 ka BP (Marks, 2002). During the older pre-maximum Świecie Stadial of this glaciation, dated at about 70-60 ka, the ice sheet was more limited and occupied mostly north-eastern part of Poland (Wysota, 2002). In the southernmost part of the extraglacial area in Poland, 2-3 loess horizons, defined by Maruszczak (1991) as the younger loess, were deposited during the anaglacial part of the Vistulian Glaciation. In numerous sections of the Głubczyce Plateau, Małopolska Upland, Lublin Upland and Carpathian Highlands these loess deposits contain interstadial palaeosols. Basing mostly on TL dating, these loess deposits were formed from about $100 \mathrm{ka}$ to about 15/12 ka (Maruszczak, 1991). Interstadial soils, preserved in Polish loess sections, developed during warmings at 80-75 ka, 55-50 ka and 32-28 ka. In the main loess sections of the Volhynian Upland i.e. at Bojanice and Korshiv (Fig. 3), they correspond to loess and separating palaeosols of the Valdai loess horizon (Boguckij et al., 1980; Bogucki et al., 1994). The oldest ones constitute presumably the upper part of the Horokhiv soil complex whereas the overlying Dubno, Rowne and Krasilov soils can be the equivalents of interstadial warmings, recorded in Polish loess and 
separating stadial advances during the Vistulian Glaciation in Poland.

\section{FINAL REMARKS}

Presented outline of stratigraphy of the Polish Pleistocene comprises its glacial part with 8 glaciations and 7 interglacials (cf. Lindner et al., 1995; Marks, 2000), grouped lately (cf. Ber et al., 2007a, b) into 3 complexes: South-Polish, Middle-Polish and North-Polish ones. The new approach in the presented outline is firstly a complete description of 2 oldest interglacials: Augustovian and Kozi Grzbiet (Domuraty) and secondly, a presentation of the opinion on separation of the Krznanian Glaciation as the older one than the Odranian Glaciation, the latter with 3 recessional stades (Warta, Wkra and Mławka).

\section{ACKNOWLEDGEMENTS}

This approach was presented by the authors (Lindner and Marks, 2007) at the 14th Ukrainian-Polish Symposium "Stratigraphic correlation of loesses and glacial deposits of Poland and Ukraine", organized on September 12-16, 2007, in Luck (Ukraine) on the topic "Problems of the Middle Pleistocene interglacial". During this symposium possible correlation of the Pleistocene glaciations and interglacials in Poland with main Pleistocene stratigraphic horizons recorded in western Ukraine was presented. The correlation was done especially for two key loess sections in the Volhynian Upland (Bojanice and Korshiv). In these sections there are all younger Pleistocene coolings (glaciations) and warmings (interglacials), indicated one above the other, from the Sanian 1 (Don, Sula) to the Vistulian (Valdai) Glaciation.

\section{REFERENCES}

Bałuk A, 1991. Quaternary of the Lower Narew River Basin, northeastern Masovia. Prace Państwowego Instytutu Geologicznego 130: 173.

Ber A, 2000. Pleistocene of north-eastern Poland and neighbouring areas against crystalline and sedimentary basement. Prace Państwowego Instytutu Geologicznego 170: 1-80.

Ber A, Lindner L and Marks L, 2007a. Proposal of a stratigraphic subdivision of the Quaternary of Poland. Quaternary International 167-168 Suppl.: 32, DOI 10.1016/j.quaint.2007.04.001.

Ber A, Lindner L and Marks L, 2007b. Proposal of a stratigraphic subdivision of the Quaternary of Poland. Przeglad Geologiczny 55(2): 115-118.

Boguckij AB, Wieliczko AA, Gerenczuk KI, Gruzman GB, Demediuk NS, Zalesskij II, Krawczuk JS, Morozowa TD, Neczajew WP, Palienko WP, Cackin AI and Czugunnyj JG, 1980. Opornyje razrezy i krajewyje obrazowanija materikowych oledenenii zapadnoj czasti Ukrainy (Outcrops and marginal glacial formations in western Ukraine). Institut Geologicheskich Nauk AN USSR Preprint 80-17: $1-51$.

Bogucki A, Bogucki A and Wołoszyn P, 1994. Reperowy profil Bojanice $i$ niektóre problemy badawcze lessowo-glebowych serii peryglacjalnych plejstocenu (Stratotype section Bojanice and some research problem of loess-palaeosol periglacial series of the Pleistocene). In: Wilgat T, ed, Przewodnik wycieczkowy Ogólnopolskiego Zjazdu Polskiego Towarzystwa Geograficznego. Towarzystwo Wolnej Wszechnicy Polskiej, Oddział w Lublinie: 246-249.

Bogucki AB, Maruszczak H and Nawrocki J, 1995. Stratigraphic and Paleogeographic Interpretation of Analysis Results of Magnetic Susceptibility of Loesses in Bojanice (NW Ukraine). Annales Universitatis Mariae Curie-Sklodowska B 50: 51-64.
Boguckyj A and Łanczont M, 2002. Loess stratigraphy in the Halyc Prydnistrov'ja region. Studia Geologica Polonica 119: 315-327.

Butrym J and Zuchiewicz W, 1985. Results of thermoluminescent datings of Quaternary sediments from the Nowy Sacz Basin (West Carpathians). Przeglad Geologiczny 33(3): 126-136.

Dolecki L, 2002. Main profiles of the Neopleistocene loesses on the Horodto Plateau-ridge and their lithological-stratigraphical interpretation. Lublin, Wydawnictwo Uniwersytetu Marii CurieSkłodowskiej: 263pp.

Głazek J, 1984. First isotope datings of speleothems from Tatra caves and their bearing on Pleistocene stratigraphy of the Tatra Mts. Przeglad Geologiczny 32(1): 39-43.

Głazek J, Sulimski A, Szynkiewicz A and Wysoczański-Minkowicz T, 1976. Middle Pleistocene karst deposits with Ursus spelaeus at Draby near Działoszyn, Central Poland. Acta Geologica Polonica 26(3): 451-466.

Głazek J, Kowalski K, Lindner L, Młynarski M, Stworzewicz E, Tuchołka P and Wysoczański-Minkowicz T, 1977. Cave deposits at Kozi Grzbiet (Holy Cross Mts, Central Poland) with vertebrate and snail faunas of the Mindelian I/Mindelian II Interglacial and their stratigraphic correlation. Proceedings 7 th International Speleological Congress, Sheffield: 211-214.

Harasimiuk M, Maruszczak H and Wojtanowicz J, 1988. Quaternary stratigraphy of the Lublin region, southeastern Poland. Quaternary Studies in Poland 8: 15-25.

Janczyk-Kopikowa Z, 1991. Problems of the palynostratigraphy of the Pleistocene in Poland and the palynological analysis of interglacial deposits from Besiekierz (Central Poland). Annales Universitatis Mariae Curie-Sklodowska B 46 Suppl. 1: 1-26.

Janczyk-Kopikowa Z, 1996. Temperate stages of the Mesopleistocene in NE Poland. Biuletyn Państwowego Instytutu Geologicznego 373: 49-66.

Jersak J, 1973. Lithology and stratigraphy of the loess on the southern Polish Uplands. Acta Geographica Lodziensia 32: 1-139.

Krupiński KM, 2000. Palynostratigraphic correlation of deposits of the Mazovian Interglacial of Poland. Prace Państwowego Instytutu Geologicznego 169: 1-61.

Krupiński KM and Marks L, 1986. Interglacial sediments at Losy, Mazury Lakeland. Bulletin of the Polish Academy of Sciences, Earth Sciences 34(4): 375-386.

Krzyszkowski D, Dobracka E, Dobracki D, Czerwonka JA and Kuszell T, 1999. Stratigraphy of Weichselian deposits in the cliff sections between Łukęcin and Niechorze, Baltic coast, north-western Poland. Quaternary Studies in Poland 16: 27-45.

Lindner L, 1991. Stratigraphy of main Pleistocene loess horizons and paleosols in mid-eastern Europe. Acta Geologica Polonica 41(12): $85-100$.

Lindner L, 2001. Problems of the age and extent of the Scandinavian glaciations at the margin of the Polish Carpathians (southern Poland). Przeglad Geologiczny 49(9): 819-821.

Lindner L, 2005. A new look at the number, age and extent of the Middle Polish Glaciations in the southern part of central-eastern Poland. Przeglad Geologiczny 53(2): 145-150.

Lindner L and Brykczyńska E, 1980. Organogenic deposits at Zbójno by Przedbórz, western slopes of the Holy Cross Mts, and their bearing on stratigraphy of the Pleistocene of Poland. Acta $\mathrm{Ge}$ ologica Polonica 30(2): 155-163.

Lindner L and Marciniak B, 1998. The occurrence of four interglacials younger than the Sanian 2 (Elsterian 2) Glaciation in the Pleistocene of Europe. Acta Geologica Polonica 48(3): 247-263.

Lindner L and Marks L, 1995. Outline of palaeogeomorphology of the Polish territory during the Scandinavian glaciation. Przeglad Geologiczny 43(7): 591-594.

Lindner L and Marks L, 1999. New approach to stratigraphy of palaeolake and glacial sediments of the younger Middle Pleistocene in mid-eastern Poland. Geological Quarterly 43(1): 1-7.

Lindner L and Marks L, 2007. New approach to stratigraphy of the Pleistocene of Poland and its correlation with the Volhynian Upland in the Ukraine. In: Boguckij A et al., eds, Problemy srednieplejstocenowo interglacjalu. Mat. IV Ukrainsko-Polskowo Seminaru, 12-16 weresnija 2007r. Luck, Ukraina. Wydaw. Centr. LNU im. Iwana Franka, Lviv: 85-95.

Lindner L and Prószyński M, 1979. Geochronology of the Pleistocene deposits exposed at Wachock, nothern part of the Holy Cross Mts. Acta Geologica Polonica 29(1): 121-132.

Lindner L, Dzierżek J, Lamparski Z, Marks L and Nitychoruk J, 1995. Zarys stratygrafii czwartorzędu Polski; główne poziomy osadów 
glacjalnych oraz ich rozprzestrzenienie. Przeglad Geologiczny 43(7): 586-591.

Lindner L, Wojtanowicz J and Bogutsky AB, 1998. Main stratigraphic units of the Pleistocene in southeastern Poland and northwestern Ukraine, and their correlation in western and mid-eastern Europe. Geological Quarterly 42(1): 73-86.

Lindner L, Bogucki A, Chlebowski R and Gożik P, 2004. The importance of glacial till occurrence in loess type sections of Poland and Ukraine. Przeglad Geologiczny 52(4): 331-335.

Lisicki S and Winter H, 2004. Revision of stratigraphical position of the Lower and Middle Pleistocene sediments of northeastern Poland. Geografia Uniwersytetu Adama Mickiewicza 68: 259-283.

Makowska A, 1986. Pleistocene seas in Poland - sediments, age and palaeogeography. Prace Instytutu Geologicznego 70: 1-74.

Mamakowa K, 1989. Late Middle Polish Glaciation, Eemian and Early Vistulian vegetation at Imbramowice near Wrocław and the pollen stratigraphy of this part of the Pleistocene in Poland. Acta Paleobotanica 29(1): 11-176.

Marciniak B, 1998. Diatom stratigraphy of the Mazovian Interglacial lacustrine sediments in southeastern Poland. Studia Geologica Polonica 113: 7-64.

Marciniak B and Kowalski WW, 1978. Dominant diatoms, pollen, chemistry and mineralogy of the Eemian lacustrine sediments from Nidzica (northern Poland), a preliminary report. Polish Archives of Hydrobiology 25(1-2): 269-281.

Marciniak B and Lindner L, 2003. Diatoms and geology of the Ferdynandovian Interglacial lake sediments in Poland. Botanical Guidebooks 26: 199-215.

Marciniak B and Winter H, 2003. Les assemblages de diatomées et de pollens dans les sediments lacustres interglaciaires du Pléistocène inférieur en Pologne. In: 22ème Colloque de l'Association de Diatomistes de Langue Française (ADLaF) Espet, Catalogue, Espagne, 9-12 Septembre 2003: 28.

Marks L, 1998. Middle and Late Vistulian Glaciation in Poland. Geologija 25: 57-61.

Marks L, 2000. Outline of most questionable items of the Quaternary stratigraphy in Poland. Litosphere 12: 28-36.

Marks L, 2002. Last Glacial Maximum in Poland. Quaternary Science Reviews 21(1-3): 103-110, DOI 10.1016/S0277-3791(01)00086-5.

Marks L, 2004a. Pleistocene Glacial Limits in Poland. In: Ehlers J and Gibbard PL, eds., Quaternary Glaciations - Extents and Chronology. Elsevier BV: 295-300.

Marks L, 2004b. Ice-sheet limit of the Warta Glaciation in Poland. In:
Harasimiuk M and Terpiłowski S, eds, Zlodowacenie warty w Polsce. Lublin, Wydawnictwo UMCS: 27-35.

Maruszczak H, 1991. Stratigraphic differentiation of Polish loesses. In: Maruszczak H, ed., Podstawowe profile lessów w Polsce. Wydawnictwo Uniw. M. Curie-Skłodowskiej A: 13-35.

Nawrocki J and Siennicka-Chmielewska A, 1996. Loess magnetism in the Odonów section (S Poland). Geological Quarterly 40(2): 231244.

Nawrocki J and Wójcik A, 1995. Lithology and stratigraphy of Pleistocene loess-like deposits in the Załubińcze section (Nowy Sącz Basin - Outer Carpathians). Geological Quarterly 39(1): 121-144.

Pidek IA, 2003. Mesopleistocene vegetation history in the northern foreland of the Lublin Upland based on palaeobotanical studies in the profiles from Zdany and Brus sites. Wydawnictwo Uniw. M. Curie-Skłodowskiej: 1-96.

Rzechowski J, 1996. The Ferdynandovian Interglacial in the stratotype profile at Ferdynandów (southeastern Mazowsze). Biuletyn Państwowego Instytutu Geologicznego 373: 161-171.

Szełkoplyas WN and Christoforowa TF, 1987. Sledy rannieplejstocenowych oledenenii na territorii Ukrainy (Traces of Early Pleistocene glaciations in the territory of the Ukraine). Naukowa Dumka: 7-14.

Szełkoplyas WN, Christoforowa TF, Palienko WP, Morozow GW, Maruszczak H, Lindner L, Wojtanowicz J, Butrym J and Boguckij AB, 1985. Chronologija obrazowanii lesowoj $i$ lednikowoj formacji zapadnoj czasti USSR $i$ sopredelnych territorii (Chronology of loess and glacial deposits in the western part of the Soviet Union and adjoining areas). Institut Geologicheskich Nauk AN USSR Preprint 85-18: 1-51.

Szponar A, 1986: Chronostratigraphy and the stages of deglaciation in the Sudetes Foreland area during the Middle-Polish glaciation. Acta Universitatis Wratislaviensis 963, Studia Geograficzne 45: 1202.

Winter H, 2001. New profile of Augustowski Interglacial in northeastern Poland. Geografia Uniwersytetu Adama Mickiewicza 64 439-450.

Wójcik A, Nawrocki J and Nita M, 2004. Pleistocene in the Kończyce profile (Oświęcim Basin) - sediment genesis and age analysis at the background of stratigraphic scheme of the Quaternary. Biuletyn Państwowego Instytutu Geologicznego 409: 5-50.

Wysota W, 2002. Stratigraphy and sedimentary environments of the Weichselian Glaciation in the southern part of the Lower Vistula region. Rozprawa habilitacyjna,Uniwersytetu Mikołaja Kopernika w Toruniu: $1-144$. 